\title{
Study of College English Autonomous Learning Mode based on
}

\section{Computer and Network Technology}

\author{
Ming $\mathrm{Li}^{1}$ \\ ${ }^{1}$ Henan Finance \& Taxation College, Zhengzhou, 451464 \\ 346591653@163.com
}

\section{KEYWORDS: English Learning; Autonomous Mode; Computer Technology}

\begin{abstract}
The development of multimedia and network has greatly facilitated the reform in college English teaching. This paper introduces the reformative computer-and-network assisted autonomous learning mode in college English at Southeast University and analyzes the students' attitudes towards this new mode on the basis of the data collected in three questionnaires. After listing the advantages of the new teaching mode compared with the traditional one, the paper points the causes of the existing problems in the process of teaching and learning.
\end{abstract}

\section{Introduction}

Autonomous learning is an origin of humanism, and as cognitivism, constructivism rise gradually develop and mature new teaching philosophy, it refers to the learner consciously determine learning objectives, learning objectives, selecting learning methods, monitoring the learning process, the results of the evaluation of learning process. From the beginning of the 1950s, self-learning and gradually become an important issue of Western Educational psychologists study, they study based on self-learning system will be autonomous learning ability was established as one of the main goals of education reform. The self-learning concept was first introduced in the early foreign language learning in the 1980s formally proposed by Henri Holec, in his view from the perspective of the learner, with self-learning ability means getting identify learning objectives, content, materials and methods to determine learning time, place and progress as well as the ability to assess learning. Simply put, is "the ability to be responsible for their own learning." Since the 1990s, many Western scholars have on the theory and practice of self-learning ability were discussed and studies that enable more teachers and scholars reached this consensus: one of the important goals of education is to help people establish lifelong learning and grasp the concept of independent learning skills; and the ultimate goal of schooling is the independent learning ability of students so that they learn all kinds of knowledge not only on campus, but more importantly is to master the learning methods, learning how to learn. In China, in addition to scholars focused on the study and the need to define the independent review of research and those are also beginning to practical application independent study conducted empirical research.

\section{The Autonomous Learning Mode of English}

Survey results show that more than $60 \%$ of the teachers and students do not like the traditional teacher blackboard chalk teaching methods, the current multimedia teaching methods have been widely used in school, more than half of the teachers and students affirm its teaching effect, $72 \%$ of 
teachers about $60 \%$ of the students agreed with the use of computer networks in college English Teaching. Under the guidance of teachers, students from the discretionary learning time, select learning content and participate in the Network Teaching Mode teachers teaching counseling, is a multimedia assisted English teaching and computer network technology product of the combination as a new teaching model, in this survey it was supported by about half of the teachers and students. Change the old teaching ideas, challenging the traditional teaching methods, explore new and effective college English teaching model, it has become the consensus of the majority of teachers and students. This new self-learning teaching model has a broad theoretical basis and software support, teaching English or content from the network itself, college English autonomous learning mode is worth trying both from the students' self-learning ability, and is expected to be successful.

Based on these survey results, we have to "request" as a guide, combined with the experience and lessons Multimedia assisted college English teaching activities, the existing teaching mode reform and exploration, and implement sub-level, autonomous, personalized principles, full use of multimedia and network technology, improve the original single classroom teaching teachers teach mainly the formation of a new student-on self-study, classroom tutoring, multimedia courseware and the second classroom activities combining the integrated teaching mode.

According to the characteristics of autonomous learning, paying attention to lay the foundation of students' language, while more emphasis on the ability to develop their applications, in particular the practical ability to use English to communicate. When students reading ability, enhance their listening, speaking, writing and comprehensive training translation language skills, with particular emphasis on training and training of practical skills in oral and written, so as to achieve the "requirements" specified in / to adapt to social development and international 0 need to communicate.

From February 2004 students selected in 2003 some students in the class (including intensive courses and regular classes) based college English teaching computers and networks, the choice of materials is published by Higher Education Press' college experience English "series.

In the first survey, $79 \%$ of new university students' English teaching mode welcomed. Students generally reflect, compared to traditional classroom teaching, the new teaching model that they can really participate in the teaching process, the situation for their own independent arrangements for learning English, they think this will help to improve the teaching model of English proficiency. They generally reflect the rich network tutorials and college English learning system content, beautifully produced, $75 \%$ of students expressed satisfaction with the content and form of the use of teaching software. However, since this new teaching model of high computer and network requirements, students must have some basic knowledge of computers and networks. Most of the students in the first month of study have encountered some technical problems or operational, these problems to some extent affect the learning effect. According to the results of the first survey, we have remained at the same time original teaching arrangements for students to reflect the larger computer and network problems, technically made the necessary improvements. After two of the survey results show that after a period of practice, students new teaching mode, teaching software, content and form of satisfaction and graduate teaching assistants are maintained at more than $70 \%$ of computer equipment and network connectivity level of satisfaction also It has been some improvement. Overall, student pilot teaching two semesters is quite satisfactory. About $70 \%$ of students new teaching model positive supportive attitude, although this proportion is 79\%, compared with the initial pilot slightly lower, but it can be more objectively reflect the acceptance of this new teaching mode, there are three reasons: first, students have a fresh feeling at the beginning, but in the course of gradually found in textbooks, multimedia learning courseware, 
teaching arrangements, there are some unsatisfactory places. Thus, they become rational understanding; second, to improve English proficiency is not easy, and only after a large number of language input language is generated only when the output changes, teachers and students also need more time to appreciate the computer and the positive impact of the network to bring the college English teaching; third, some students by the examination-oriented education, expect all learning activities should conform with the University of CET exam requirements, it is also reluctant to fully accept the new teaching model.

\section{The Advantages of New Mode}

Established the dominant position of the students in the teaching process based on computer and network college English autonomous learning mode, and from teacher-centered, simple language knowledge and skills of the traditional three-P0 mode, namely presentation (teach), practice (practice) and production (output) teaching model to student-centered, both teach general knowledge and language skills, but also focus on training teaching mode transformation language competence and autonomous learning ability. Compared with the traditional teaching model, its advantages are students' individual autonomous learning. Autonomous Learning University English Autonomous Learning Model has greatest features and advantages of computer-based and network. Classroom Teaching by traditional teaching model, teachers and talk about how to speak entirely by prior arrangement and control, and the actual needs of the students are not considered likely to teachers in the classroom about the contents of the occurrence and students wishing to learn there is a big gap between the knowledge of the situation. We can solve this problem through self-learning based on student computers and networks Autonomous College English Learning. Students according to their own situation, their own way of learning, decide what to learn and how to learn, and with the help of computer and network technology, the complete learning tasks that constructivist theory emphasizes learning process according to their own learners needs, interests, hobbies, use of existing knowledge structure, namely knowledge and experience, external information proactively selection, processing and handling processes. Part there is spare capacity in the students can perform a given task of teaching in accordance with their interests autonomously learning English. Thus, the classroom time is fully utilized, but also to ensure that every student can really learn something wants to learn in English class.

Teaching Aim. Traditional teaching students did not fully consider the differences, even if teachers consider the actual needs of the students in the classroom, unified teaching model determines the best, most students can only be based on the level and arrange teaching, very likely part there is spare capacity of hungry students and part of the base case of poor students can not keep up. The new model provides only basic learning tasks, students can study at any time to seek help from a teacher or graduate teaching assistants encounter difficulties, teachers can be targeted based on individualized teaching students in learning the issues raised.

Comprehensive and balanced development of various skills is important. Strict distinction between traditional teaching intensive reading, extensive reading, listening, speaking, teaching accounted for most of the time reading, and other skills training relatively little or almost nothing. New Mode full attention to this point, the network tutorials and college English learning system combines LSDWT all other skills, especially listening and speaking skills training to improve the proportion of applications in order to improve students' comprehensive English ability.

\section{Conclusion}


Computer and network-based College English Autonomous Learning are in teaching philosophy, teaching ideas and teaching methods in a new attempt. In the pilot teaching, we found that students who tremendous learning potential, as long as reasonable arrangements for teaching, students learn not only to complete the task, but also to cultivate self-learning ability, and benefit in future studies. We can say that this new model has begun to show superiority. However, we must also recognize that the effect of the new model and teaching is closely related to the content and technical support, which should be our future research directions.

\section{REFERENCE:}

[1] Benson, K. The philosophy and politics of learner autonomy [C]. In P. Benson and P. Voller (eds ) Autonomy and Independence in Language Learning. London: Longman, 1997.

[2] Dickinson, L. Autonomy and motivation: a literature review[J]. System, 1995, 23(2): 165 -174.

[3] Benson, P. \& P. Voller (eds.). Autonomy and Independence in Language Learning [M]. London: Longman, 1997.

[4] Candy, V. Self-direction for Lifelong Learning [M]. California: Jossey-Bass.1991.[10] Cook, V. Linguistic and Second Language Acquisition [M]. London: Macmillan.1993. 